\title{
Engagement, Gentrification, and the Neoliberal Hijacking of History
}

\section{Citation}

Herzfeld, Michael. 2010. "Engagement, Gentrification, and the Neoliberal Hijacking of History." Current Anthropology 51 (S2) (October): S259-S267. doi:10.1086/653420.

\section{Published Version}

$10.1086 / 653420$

\section{Permanent link}

http://nrs.harvard.edu/urn-3:HUL.InstRepos:34353686

\section{Terms of Use}

This article was downloaded from Harvard University's DASH repository, and is made available under the terms and conditions applicable to Other Posted Material, as set forth at http:// nrs.harvard.edu/urn-3:HUL.InstRepos:dash.current.terms-of-use\#LAA

\section{Share Your Story}

The Harvard community has made this article openly available.

Please share how this access benefits you. Submit a story.

Accessibility 


\title{
Engagement, Gentrification, and the Neoliberal Hijacking of History
}

\author{
by Michael Herzfeld
}

\begin{abstract}
Drawing primarily on fieldwork in Greece, Italy, and Thailand, I examine the use of historic conservation to justify gentrification. This commoditization of history expands into urban design a classification that serves the goals of neoliberal modernity. By thus refocusing the classic anthropological concern with taxonomy on the analysis of the bureaucratic production of everyday experience and knowledge, I explore a new global habitus in which dominant interpretations of history spatially reinforce current ideologies. Historic conservation often provides an excuse for intervention into urban life. In a revision of high modernism's focus on science, logic, and efficiency, this trend invokes "the past." But which past? The concept of "heritage" is grounded in culturally specific ideologies of kinship, residence, and property, but the universalization of the nation-state as a collectivity of similar subunits has given those concepts globally hegemonic power. In consequence, phenomena that governments treat as "merely" cultural or symbolic are not taken seriously as sources of poverty and subjection. By juxtaposing historic conservation and gentrification with a critique of the public management of knowledge, I thus sketch a critical trajectory for anthropological engagement in "the politics of mereness" by asking who defines what matters in residents' lives.
\end{abstract}

Many ethical issues in anthropology arise from a conflict of values that in its complexity far exceeds simplistic dualisms of good and evil. Such is the relationship between historic conservation, an ethical good from the perspective of both archaeological scholarship and ideological patrimonialism, and respect for established, living communities whose existence is sometimes threatened by planners' desire to monumentalize and compartmentalize and by national governments' prioritizing of collective over local goals. At the same time, it is important to recognize that localist ideologies may also turn repressive, especially in relation to minority groups and the economically weaker segments of dominant populations, so that simply reversing the priorities_elevating the local over the national, for example-does not automatically resolve injustices.

The sometimes mutually opposed ethics of conservation and of housing rights thus frequently come into conflict at multiple levels. That conflict sometimes turns violent and is usually highly acrimonious, given that both sides regard their immediate preoccupations as representing the highest good. On the one hand, we find a rhetoric of heritage held in trust for future generations and representing a collective past and

Michael Herzfeld is Professor in the Department of Anthropology, Harvard University (William James Hall, 33 Kirkland Street, Cambridge, Massachusetts 02138, U.S.A. [herzfeld@wjh.harvard.edu]). present identity; on the other, we find an equally unyielding rhetoric concerned with human dignity and legal rights. Such confrontations are especially heated when, in the context of neoliberal concerns with efficiency, governments and private enterprises treat conservation in purely economic terms, whether as an expense to be contained or as a source of profit. Real estate speculation and the added value of heritage force prices and rents into wildly unpredictable but usually dramatic escalation. The impulse to preserve, the desire to render comfortable, and the sheer need of a place to serve as home are three human trajectories that converge, sometimes with tragic consequences, wherever relatively poor people live in areas earmarked for "urban improvement"-a euphemism, as Neil Smith (2006) reminds us, for the disruptive force of gentrification.

I start this discussion from the premise that all conservation involves some degree of selection and often also of actual physical modification. That being the case, I also take it as axiomatic that all conservation schemes can, to some extent, be adjusted to meet the needs of local populations and that under ideal conditions, those populations can be trusted to invest in the continuing upkeep of the historical fabric as long as they have reason to feel that it in some way belongs to them.

But this is not the usual perception. On the contrary, both state-sponsored historic conservation and-perhaps especially-capital-driven gentrification almost always bring the 
tragedy of eviction in their train. Only when householders are also owners, and thereby able to improve their own economic condition along - and through — the increased value of their properties, can they avoid being cast on the rubbish heap of history. This happier scenario does occur. It happened, for example, in the small Cretan town of Rethemnos, where I conducted research on the impact of historic conservation laws in the 1980s (Herzfeld 1991); not only were the residents owners of their homes, but by the time the value of real estate had really begun to escalate in earnest, they had become savvy entrepreneurs fully aware of the material advantages of living in houses acknowledged by the authorities as "historic" and greatly attractive to (especially) foreign tourists. The locals flourished as hoteliers and shopkeepers, and their once dilapidated old houses, now blessed with the empowering label of "Venetian" (or at least "traditional"), captured both the imagination and the cash the tourists brought. ${ }^{1}$

But in most places-such as the communities in Rome and Bangkok where I have worked more recently-the effects on a population predominantly made up of renters has been nothing short of catastrophic (see Herzfeld 2003, 2006, 2009). In Rome, in the central district of Monti (located roughly between Santa Maria Maggiore and the Colosseum), the escalation of prices resulted from a rash of real estate speculation. In Bangkok, political and symbolic claims to the highly visible segment of the old Siamese capital and dynastic monumental complex in which the Pom Mahakan community lived were linked both to concerns about potential drops in property values and to the authorities' desire to create a sacred space that would be off-limits to ordinary residents.

These two cases nevertheless do have a common dimension. Because the preservation of heritage has been the motivation for both, I argue that the rather academic-sounding topic of heritage and history is not irrelevant to the needs of the victims. Indeed, there are two excellent reasons for pursuing it: first, because its allegedly overriding importance is used as a justification for occasionally horrendous acts of violence and dispossession, and second, because the reaction to it often includes a form of fervent localism that all too easily translates into ethnic prejudice-in a word, racism — in a dynamic that further isolates the victims and also turns them into potential victimizers as well. ${ }^{2}$ Even when local residents make an appeal to national sentiment as a justification for their struggle, they may at least implicitly exclude others. "We are Thai people," said the residents of Pom Mahakan, even as their leaders also sought to emphasize their Buddhism-based Thainess through

1. Being "Venetian" was considered an advantage because, especially in contrast to the despised label of "Turkish" (i.e., Ottoman), it placed the owner's cultural capital squarely in "the West" and thus aligned the owner with the dominant ideology of the Greek nation-state. The label of "traditional," while less useful in securing funding from the national archaeological service, played an important role in promoting boutique hotels and tourist gift shops.

2. On homelessness, see Desjarlais (1997) and Marcus (2006); on gentrification, see Smith (2006). acts of charity (especially toward the victims of the 2004 tsunami in the largely Muslim and Malay-speaking segments of the southern part of the country). When such declarations do not swiftly morph into forms of intolerance in practice, we may be able to recognize the wisdom and restraint of particular local leaders; the more negative result, in which localism becomes a form of exclusion, often instead follows the bad example set by municipal or national politicians. These are unequivocally matters that deserve and indeed demand serious analysis, and they bring into sharp focus the key dilemma with which I opened this discussion: in a contest between living people and objects from the past, need one side vanquish the other for a persuasively ethical solution to emerge?

Most evidently at stake here is a choice between economic and other values. The globally dominant economic ideology we usually know as neoliberalism opposes the interests of local people and favors those of speculators and bureaucrats, subjugating the residents' lives to impersonal imperatives masquerading as "improvement" and "development."3 (Its local representatives usually claim that they are upgrading the quality of the neighborhood, but it soon becomes apparent that they have neither consulted the local residents nor tried to live among them in order to appreciate the importance of place in their sense of collective identity.) This is not a conclusion to which a scholar would necessarily come through study in the library, but anthropologists, working in the field, rapidly undergo an intense socialization into precisely these dimensions of the conflict.

Indeed, a seriously engaged anthropology capable of opposing such trends does not, necessarily, or even easily, arise from carefully programmed applied work. Instead, it emerges from the serendipitous nature of field research itself. For potentially hostile critics, especially officials whose entire outlook is circumscribed (or, rather, shielded) by what Richard Wilson and Jon Mitchell (2003:10) have called "documentary legal fetishism" and who work within a tradition of legal positivism in which definitions trump narratives, ${ }^{4}$ such a rejection of

3. The term neoliberalism is a generalization that incorporates several distinct ideological strands. For present purposes, however, I prefer to treat them all as sharing the common argument that freedom of choice and opportunity should render questions of economic justice irrelevant (or, at best, constitute true economic justice); in virtually all versions, the weak go to the wall. This, for example, is the logic of "improving a neighborhood," a rhetorical strategy that disguises the brutality of the eviction of those unable to resist the economic might of the financial speculators.

4. For a critical discussion of another instance of legal positivism, from Greece, see Pollis (1987). In the Pom Mahakan case, the legal decision that a "public park" (suan sattharana) and a residential presence were mutually incompatible seems to have sprung from this decision and forms the basis of the most recent official attempts to expel the residents (I return to this development later in the article). The residents had earlier countered such implications by creating their own "public garden" (also suan sattharana in Thai), but the authorities had quickly destroyed this evidence of an alternative perspective and dumped truckloads of garbage onto the residents' creation in order to give greater symbolic and material 
formal method must itself seem suspect, and anthropologists usually have a hard time explaining the value of their work to bureaucrats of this persuasion. Anthropologists also risk alienating well-meaning activists. These activists, who have often enjoyed a long association with NGOs, sometimes hold a narrowly Western-derived view of social justice. This orientation sometimes leads them to look for finite solutions and to "detemporalize and decontextualize" in ways that conflict with perspectives derived from the experience of longterm, deeply engaged fieldwork. ${ }^{5}$

My active participation in the struggle of the Bangkok community of Pom Mahakan to remain located on its present dwelling site, in the middle of a monument claimed as historic by the national ideology and the municipal authorities, thus elicited skepticism from positivistic social scientists, members of the public, and numerous officials, all of whom raised doubts that I would have good, uncontaminated data. How, they variously demanded, could I expect to be objective when I was so passionately committed? That question further highlighted for me the fact that an objectivist (Bourdieu 1977: 3-4) position was not merely untenable but was in fact part of the problem. The residents of Pom Mahakan, a largely recent accretion of residents from around the country and now occupying a piece of prime real estate between the circumvallation of the old Bangkok royal city of Rama I and one of the most important remaining canals, find themselves in a fight against administrators who have largely persuaded their public of the unimpeachable rationality of legal arguments that are, in reality, embedded in arbitrary definitions and circular arguments.

The positivism of official discourse is thus central to the residents' problems, although they have developed a remarkable capacity to adapt it to their own purposes. Like the inhabitants of so many other Thai communities facing eviction, they live in a world in which the concept of "data" (khaw muun) has been hypostatized by market forces as a weapon of the extraordinarily strong-as a justification for sometimes violent depredations against the poor. I found it interesting that they and their supporters often in turn invoked the notion of data to describe the key elements of their self-defense and came to realize that they had little choice but to follow this modality in a contest largely dominated by a positivistic state modeled on colonial prototypes. ${ }^{6}$

To those who questioned the scholarly appropriateness of my direct involvement in the struggle of the people of Pom

force to the destruction. Questions of legal theory have real implications for the way events unfold.

5. I take this expression from Lynn Meskell's (2009:xxxiii) critique of theories of social justice that seem especially incompatible with debates over the complexities of heritage management and ownership.

6. I use this rather cautious formulation because Thailand was never officially a colony of any foreign power, although it has certainly been subject to strong external interference by Western colonizers and their local client elites. See Herzfeld (2002), Hong (2004), Jackson (2004, 2007), and Thongchai $(2001,2002)$.
Mahakan, I answered in their own terms - those of data quality. Above all, that engagement allowed me access to information (a much better word than data) I would otherwise never have been allowed to acquire, especially after I joined them in their barricaded community on the day they thought the authorities were about to "invade," with possibly violent and even fatal repercussions. In response to the objections, I began to wonder whether the so-called objective judgment demanded by my critics might perhaps be dependent on not having enough information. This is especially ironic in that quantity seemed to be a key concern of theirs. Charges that Pom Mahakan contained "only" 282 people, or that the residents of the house in Rome where I became similarly involved in a struggle against eviction were "only" 10 families (and not especially poor at that), represent significance in terms of numerological incantation capable of eliciting strong public support for the purported logic of a stance that actually opposes the interests of that same public by overlooking the emblematic importance of a small sample.

Small, however, does not necessarily mean insignificant. What was done to the people of Pom Mahakan could a fortiori happen to much larger populations, and indeed that appeared to be the longer-term plan. There are many such small communities along Rajdamnoen Avenue, and all of them, although to varying degrees, thwarted the planners' desire to create order (khwaam mii rabiab) and beauty (khwaam suay ngaam) by removing the messiness of human presence. Pom Mahakan was evidently the leading domino, and its fall would have been the signal for a massive intervention all along that wide thoroughfare. The threat of even wider repercussions also lurked not far below the surface of official pronouncements; indeed, the leaders of Pom Mahakan insisted that their case was part of a larger pattern demanding solidarity among the poor (a strategy that helped to cement their alliance with numerous other communities similarly resisting eviction and contributing labor and moral support to the Pom Mahakan cause). In the same way, the besieged denizens of the historic center of Rome quickly latched on to a friendly politician's pronouncement that they represented an "emblematic" example of a once dominant social formation. ${ }^{7}$

Furthermore, the idea that such a small community was intrinsically unimportant illustrates a key dimension of the local "politics of significance" (Herzfeld 1997), locally orchestrated in terms of a populist anti-intellectualism typical of the stance of then prime minister Thaksin Shinawatr. Thaksin often lumped academics and NGO activists in a common roster of enemies; indeed, his most energetic critic and favorite target before his fall from power during the 2006 coup was an anthropologist, Thirayuth Boonmee.

7. The politician was then senator Athos De Luca, a member of the Green Party and something of a housing rights activist as well as a conservationist (see Herzfeld 2009:278). For a useful account of a major phase in the development of solidarity among Thailand's poor, see Massingham (2003). 
Such anti-intellectualism is particularly hostile to disciplines like social and cultural anthropology, with its insistence on what outsiders often see as trivial or abstruse detail. Nationalists are especially allergic to disciplines that, through their very practices, combat their numerological dismissal of minority population as, quite simply, too small to be worth bothering about, and they find it very easy to appeal to populist notions of "science" in order to portray anthropology as concerned with the trivial, the anecdotal, and the merely silly. ${ }^{8}$ Such mischievous misrepresentations easily gain wide public purchase because they appeal to the currently worlddominant definition of common sense. There is thus always both pressure and temptation to surrender to this way of thinking and to renounce the technical concerns of our discipline in order to meet the criterion of social relevance.

One of the planks in the populist platform concerns the notorious academic penchant for obscure language. Whether such language is ever necessary is a good question, requiring a thoughtful and case-specific response. Tactically, there seem to be good reasons to avoid it; it has exposed anthropology to a great deal of undeserved ridicule. On the other hand, the use of jargon does not automatically disqualify the ideas it is used to express. We cannot afford to throw out the scholarly baby with the bathwater of obscurantism.

The differential uses of history to challenge the heritage industry illustrate this key point. It is not as though the idea of heritage is unimportant to the anti-intellectual forms of populism; on the contrary, it is the linchpin of some of the most egregiously chauvinistic ideologies in the world today. Its emotional appeal gives archeology a powerful grip on the collective imagination, sometimes investing historically debatable territorial claims with apparently incontrovertible academic authority (see, e.g., Abu-El Haj 2001; Hamilakis 2007: 14-15). But the notion of heritage itself requires careful analysis rather than-to suggest a useful antidote to the epithet "jargon"-sloganeering. If we want to avoid Eurocentrism, we should be especially careful not to forget the roots of the concept of heritage in specifically Western notions of inheritance and kinship; some of the terms used for it-patrimoine in French, patrimonio in Spanish and Italian—make that even clearer and invoke specifically patrilineal norms in the bargain. ${ }^{9}$ The universalizing of Western concepts has not ceased simply because some anthropologists and others object to it.

It is no coincidence that heritage has also gained great prominence as neoliberal forces - as in both Rome and Bangkok-have seized on the commercial value with which it invests what had hitherto been treated as dilapidated old properties, or, in Thompson's (1979) term, rubbish. It is thus especially important in this particular arena that our strictly scholarly work should not be shunted aside in favor of pop-

8. I have elsewhere discussed these tactics in the Greek context; see especially Herzfeld (2005:138).

9. For a more extended discussion and further references, see Herzfeld (2009:3, 313). ularizing and simplification. We should not passively accede to the assumption that small communities are irrelevant to the future of humanity; the questions they raise about official historiography are often a salutary reminder that humanity has more than one narrative up its sleeve. In this sense, defending such communities becomes a defense of the scholarly enterprise itself.

I did not begin work in Pom Mahakan with any intention of becoming embroiled in its politics. Indeed, I did not really intend to work there at all. I was conducting research on the Rattanakosin Island Project, a development plan for the old dynastic capital of Thailand that, I thought, would give me useful insights into the links between present-day politics and the significance of historic buildings, and I had been looking at several other communities. I was invited to Pom Mahakan after some NGO activists, knowing that a certain Harvard professor was around, had apparently decided that getting me involved might bring some symbolic weight into their court. But the benefits were not one-sided. It was only when I acceded to an invitation to visit the community during a time of protest that I began to realize that this was the chance I had been awaiting.

Not only was the community seemingly obsessed with history, because its leaders realized that historical claims offered what was probably their only realistic chance to force recognition from the municipal authorities, but also they were glad to have whatever symbolic capital they thought I could bring to bear on the local authorities. Even more important, they were pleased that I did not immediately promise them that I would support their cause-indeed, I had told them I would not do so until I had examined their situation to my own satisfaction. I pointed out that there were sometimes public imperatives that could conceivably override the demands of local community interests, and I wanted to think about that possibility. I explicitly framed my caution about not making rash promises in contrast to the operating mode favored by politicians. In the end, however, I quickly decided that the construction of an empty lawn in place of a vibrant community had nothing to recommend it, especially when set against the sheer suffering that forced relocation would entail.

Thus, I did not pursue engagement for its own sake. I did, however, discover that scaling the size of my "field site" down to this tiny community actually intensified my access to intimate information, placed my work more palpably in the midst of a nationwide network of activists and students, and allowed me to view the entire Rattanakosin Island Project from the perspective of some of its economically least privileged residents. It also proved to be a remarkable microcosmic mirror for almost the entire range of Thai politics. In other words, the reduced scale served my research well; less was more. The criterion of sample size was spectacularly irrelevant to the depth of insight and access to which I became privy.

To be sure, the idea that this was an "insignificant" com- 
munity - that it was too small to be worth bothering about, given the huge problems in Bangkok's slums and the much larger eviction plans that were already in motion elsewherewas clearly an issue for the residents themselves; they saw themselves as emblematic of "small folk," although from my point of view that was precisely what made them more interesting and representative of the population at large. In a sense, those who felt that other, larger sites with more obvious problems-abject poverty, drugs, frequent violence-deserved more immediate attention were right. But it is important to remember that I did not enter Pom Mahakan as an intentional activist; I became involved in their cause through the gradual development of friendships and scholarly interest. ${ }^{10}$ If their problems were going to prove more manageable, so much the better; their solution might then become a model for tackling similar problems on a larger scale. This perspective apparently, and I suppose understandably, particularly displeased some of the bureaucrats, who at the very least faced the risk of an increased work load as the potential significance of Pom Mahakan for the larger scale of social activism became increasingly clear to the public.

The residents of Pom Mahakan themselves were the main reason for my decision to endorse their project of becoming guardians of the historic site in exchange for the right to continue living there. They were certainly not as desperately poor as the more indigent residents of Klong Toey, the most notorious Bangkok slum, but with an adult unemployment rate estimated at around $70 \%$, they were certainly in trouble. They dealt with their problems collectively; whenever a family was in difficulty, the entire community would meet to help it overcome its problems. Again, the community had formerly been prey to a fairly serious drug problem, which was one of the scourges of Klong Toey; this gave their bureaucratic opponents a handy weapon that the latter were quite willing to use. But in fact the community had already dealt with this issue in impressive fashion-and, interestingly, in a way that showed that the leaders, at least, had important and socially useful connections with the national police.

These leaders had collaborated with local police representatives to pressure the few pushers who had been active in the community into either leaving or abandoning their trade. This project was accomplished with none of the violence of Thaksin's infamous "war on drugs." Instead, several of the community leaders were given the status of "community police" (tamruat chumchon) and were given powers of arrest after being trained by local police with whom they thereby established what was to prove a useful rapport in the longer term (and indeed up to the present). They forced the few

10. Compare, for example, the massive problems of the drug-infested slums of Klong Toey (Bangkok's port area) and the heroic efforts of the famous Father Joe Maier (see Maier 2002). Father Joe himself did not have time to invest in Pom Mahakan. He did tell me, however, that he had no objections to my own involvement, simply recognizing that the sheer scale of the difficulties of Klong Toey precluded his extending himself any further. pushers who were active to decide between leaving the community and desisting from their trade, and they conducted educational sessions to make sure that parents and children were aware of the dangers-including that of social exclusion-that drugs represented. By the time I arrived, it was clear that the problem no longer existed in any substantial sense. Bright-eyed, clean children and adolescents ran happily around the community's spaces, the clearest evidence-as was pointed out to me-that this place was virtually drug free.

Some municipal officials nonetheless continued to claim, mendaciously, that the drug problem had persisted and typified the community. At the very least, these officials were guilty of ignorance; more uncharitable interpretations nevertheless might seem justified in view of their clear desire to be rid of the Pom Mahakan community once and for all. One very high-ranking city official gave the drug issue as a key reason for which I should avoid Pom Mahakan altogether. This particular official was later seen walking past the community as though no one she knew lived there, a stance that enabled her to persist in her politically useful ignorance of the actual situation but that signified to the residents little more than a refusal on her part to acquire any knowledge that might cause her to change her mind.

My interest in Pom Mahakan was undoubtedly inconvenient for many — if not all_of the municipal bureaucrats. The tiny community was already a thorn in their side as they sought to take effective control of the symbolically important dynastic center, and they only wanted to be rid of this nuisance-for that is how they clearly perceived the community. At least for the moment, they were thwarted, although the final outcome is still not certain as this article goes to press. Slated to be the first of many communities in the project area to undergo forced relocation, presumably in part because it was among the demographically smallest and economically weakest, Pom Mahakan had managed to galvanize public opinion and to deploy an impressive array of academic support to a point at which the authorities felt compelled to resort to legal devices instead of the relatively easy path of direct violence. ${ }^{11}$

A strategic focus on history gave the residents the cultural capital they needed to carry their cause into the public arena. The resulting expressions of support, which came from a wide range of academics and NGO activists (and many who were both) as well as members of the royal family and foreign observers who had learned of their story, clearly served to delay and deflect the bureaucrats' plans. The community, and those of us who worked with it, built up a "current" (krasae) of public opinion that was to prove crucial in "buying time" (soea waelaa) — a tactic used not only by the communities but

11. See especially Herzfeld (2003). The community achieved a rather sudden visibility, partly (but only to a small measure) as a result of my own writings in local newspapers, interviews with journalists, engagement in highly publicized academic conferences on its plight, and the management of a contact with the United Nations Committee on Cultural, Economic, and Social Rights in Geneva. 
also by their opponents in the city bureaucracy. Over the several years from the period of my main fieldwork to a series of brief subsequent visits, for example, I noticed that $t u k-t u k$ (three-wheel taxi) drivers, initially unaware of the community's name or even of its existence, began to recognize both (and perhaps knew me as someone who was helping the community, a point of sympathy because most of these drivers were economic refugees from the poorest part of the country). ${ }^{12}$

The resulting visibility has certainly fended off immediate violence, but questions about the future of the community persist. Despite the socially more sensitive policies of one recent governor of Bangkok, Apirak Kosayodhin, the situation remains precarious, especially as - in an act of high-modern bureaucracy that exemplifies the difficulties they face-a court ruling has recently gone against the residents' right to remain on the site on the grounds that it is incompatible to have a community and a public park in the same space. Whether this latest setback, a perfect example of legal positivism in action, will prove fatal, it is now at least somewhat more likely that the residents' demands for decent compensation will not go unrequited if they are finally forced to move out. ${ }^{13}$

This, then, is a local case that shook the conscience of a nation-so much so that even at an early point I was asked to write (or find someone to write) an article for a new periodical, Thailand Human Rights Journal (Herzfeld 2003), the first issue of which was intended to cover all the major cases current in Thailand. Pom Mahakan had certainly captured national attention. ${ }^{14}$ The involvement of numerous students-at least four master's theses were written about the site (one of which has been published in minimally updated form [Thanaphon 2007] $)^{15}$-and the interest displayed by journalists, many of whose newspapers had initially been hostile but were won over by the dignified but impassioned selfpresentation of the community leadership, have not only changed the trajectory of the community itself. The increased

12. Matters are somewhat more complex, however, because most $t u k$ tuk drivers were and are Thaksin supporters, whereas the community, having eventually been helped by prominent members of the proroyalist Democrat Party and having adopted the role of guardians of a royal architectural heritage, have found themselves aligned more convincingly, although still somewhat ambiguously, with the present government.

13. The Thammasat University archaeologist Pthomrerk Kedudhat has turned his considerable energies to community advocacy, and one of his projects concerns a close examination of the possibilities for revising the legal obstacles to the community's desire to remain on the site. Now (2009) that the same party (the Democrat Party, Paakh Prachaathipat) controls both the government and the municipality, there may be better opportunities than ever before for promoting such an initiative.

14. I accepted the invitation myself, and the article appears as Herzfeld (2003). For reasons that were never fully explained to me, the journal was forced to cease publication immediately after the release of that first issue.

15. This volume is of more than incidental ethnographic interest in the context of the politics of knowledge, because the author cites my Greek work (Herzfeld 1991) as a source of theory but makes no mention at all of my involvement with the community. visibility that the community thereby gained also enhanced a lively public discussion about the meanings of democracy, participation, and many of the other buzzwords that could, under the right circumstances, become central foci for a larger public awareness of the great disparities of wealth that exist in the country as well as of the ways in which the national history is constantly rewritten with the intention of excluding or marginalizing those groups that lack effective power.

Some years before my work in Bangkok, I had become involved in the struggles of an even smaller group of people in Rome-effectively 10 families living in a single large old house in a side street called Via degli Ibernesi. The house had been subdivided into apartments many decades before, and its residents formed a tiny microcosm of what many local observers regarded as the typical Roman neighborhood, a mixture of people of differing economic status and background. Pom Mahakan and the Via degli Ibernesi cases shared a set of important features: a small and thus manageable case that stood some chance of succeeding; visible positioning in the symbolically charged historic center of a capital city; social status that sets the group off in style and culture from both the entrepreneurial classes and the local bureaucracy; an internally somewhat diverse population; and intelligent, flexible leadership.

I would like to highlight just one of these key features. Pom Mahakan sits beside the main avenue leading down to the symbolic heart of old Bangkok, the Grand Palace, in an area much frequented by tourists and largely occupied in the daytime with a host of bureaucratic and entrepreneurial offices and in a zone of rising real estate values. Although many of its newer homes are decrepit, it boasts several wooden houses that are representative of the major phases of central Thai vernacular architecture over the past two centuries. In Rome, Via degli Ibernesi, with a commanding view down to Piazza Venezia, similarly occupies prime real estate, and the palazzo (residential building) in question forms part of a historically interesting architectural complex. The residents of both places have lived in far from ideal conditions-in Pom Mahakan most live in what are virtually slum conditions, while in Via degli Ibernesi the owners' tactics included refusing to make basic renovations in the hope that dilapidation and the absence of modern conveniences would eventually drive the residents away. ${ }^{16}$ But in neither case were the residents the poorest in town, and in no sense were they collectively dysfunctional.

Despite my growing engagement, which began in Rome and positively erupted in Bangkok, my final goal has remained the elucidation of the processes of transformation taking place in local understandings of history and temporality-in the politics of the past. This academic commitment is not antithetical to the presentist politics of my engagement. On the

16. When I told one of the Via degli Ibernesi leaders about my experiences in Bangkok, she remarked-immediately recognizing the parallels between the two cases - that truly the world was a village. 
contrary, I see social life as entailed in a complete and unhierarchized mutuality of theory and description, structure and agency, and rules and practices-parallel binary pairs to which one can easily fit the relationship between the academic analysis of changing temporalities on the one hand and the political commitment to those whose lives were disrupted by these changes on the other. For if the academic commitment had something of "structure" and "convention" about it, this gave shape and manageability to the struggles into which I was increasingly drawn; those struggles and my involvement in them, on the other hand, both shaped and changed the horizons of my research. Such a direct experience was in itself an arresting, pragmatic demonstration of the practice-theory thesis that structure and agency/practice are but two sides of the same coin.

I do not wish to imply by this discussion that we should never carry out "applied anthropology."17 But we can and should distinguish between an anthropology that sees intervention as its immediate and primary goal and one-this is what "engaged anthropology" means to me-that instead allows involvement to emerge from the academic pursuits that both led the scholar to that particular site or group and offer illuminating insights into the dilemmas faced by informants. ${ }^{18}$ This practical perspective, which more fully allows for a careful appraisal of the ethical complexity of such situations as those considered here, reflects the way in which the experiential reality of social structure always (and only) emerges in the actual performance of social interaction-in everyday life and in field research-and in which it is made palpable by creative play with its conventions (Giddens 1984:25-28; Herzfeld 2005:37, 183-199). Such a position, I suggest, goes far beyond the usual call to adopt a code of ethics. It enjoins continual watchfulness and a realization that the ultimate

17. But I do remain deeply suspicious of the genre (for useful critiques, see Escobar 1995, Ferguson 1990, Fisher 1995, and Gupta 1998).

18. History is inevitably contested. Anthropologists have known this for a long time, and the Sahlins-Obeyesekere debate (see Borofsky 1997; Obeyesekere 1992; Sahlins 1985, 1995) shows that they have themselves been far from immune to such contests - indeed, its obviously ideological contours also show rather dramatically that the idea of an objectivist approach simply reproduces the socially embedded fact that our decisions about what constitutes historical truth are often determined by social and rhetorical positioning. Aristotle understood this well when he pointed out that "metaphor" was always something other people did in contrast to one's own expertise in the literal truth (Lloyd 1990:21). The sheikhs studied by Shryock (1997) similarly understood this principle in relationship to their own segmentary decoction of the unitary pretensions of the nation-state into which a Eurocentric modernity had dragged them. It is not-contra the apparently willful misunderstanding of certain critics of a context-sensitive approach (e.g., D'Andrade 1995) — that facts do not matter, but that, as Giambattista Vico pointed out in an explicitly anti-Cartesian argument (see Herzfeld 1998:76), facts are representations, and as such, they have a material existence in the socially experienced world. Factuality is thus, to continue the same conceptual line, emergent in scholarly and political practice alike. When we examine the consequences of historic conservation and gentrification, we are faced with a selective culling of historical data for the purpose of buttressing arguments about "rights," "local identity," and so forth. ethical betrayal is to close the books on a case still in contestation or to assume that ethical principles are clearly defined and beyond discussion. I do not intend to oppose the idea of an ethical code here, but I do want to suggest that the bureaucratization of ethics can result in highly unethical or amoral stances and in forms of exclusion that have sometimes deeply painful consequences. ${ }^{19}$ Stakeholders, bureaucrats, politicians, even speculators-all have their points of view. To try to capture the entirety of this complicated mixture as a reified "culture" or to summarize an appropriate response in terms of a fixed ethical code merely occludes the allimportant detail through which we can begin to understand the situation as a process and a dynamic. I propose the term essentialist relativism for the reduction of these complexities to a single, static culture because it suggests that the entire situation is off-limits for anthropological critique, especially by outsiders. Critical relativism, by contrast, engages not only the analytic but also the political response of the anthropologist. The latter, more faithful to the model of observer participation, a term nicely echoed in NGO rhetoric, ${ }^{20}$ also recognizes the inevitability of having to perform and-in more genuinely creative moments-to deform the conventions that regulate protest and debate, thereby actively contributing to political as well as cultural processes of change. ${ }^{21}$

Here, the creative invocation of historical "rights" offered a usable and often surprisingly flexible argument against an unsympathetic state in the one case (Pom Mahakan) and the privatization of public space in the other (Via degli Ibernesi). ${ }^{22}$ Both the state and the entrepreneurs depend on a prefabricated past, producing a logic that local activists have learned to deploy against its source. I saw this in my Greek work (Herzfeld 1991), where residents could relate the historic significance of their houses to the dominant state historiography in a number of contrasting ways: those who wished to demolish and replace them called them "Turk houses," a truly derogatory term in the context of Greek nationalist rhetoric, whereas those who thought to benefit from the largesse of the national archaeological service in order to transform their homes into hotels were quick to embrace the "Venetian" (and thus "Western") label instead. Residents became particularly practiced at exploiting this binarism; because most of the houses could not be dated with any precision, they were some-

19. This, clearly, is a key problem with the requirements of committees, such as the Institutional Review Boards in the United States, that are charged with overseeing social science research on individuals and groups. These committees' procedures often seem geared more toward protecting our institutions from legal liability than toward deflecting potential harm to our interlocutors, significantly dubbed "human subjects" for the committees' purposes.

20. "Participation," too, is nevertheless subject to various forms of manipulation. All such terms, wherever they occur, should be examined in terms of how they are used in specific contexts.

21. This is a crucial aspect of what I call "social poetics," which is intended as a theory of cultural change over the long haul as well as of micropolitical interaction (Herzfeld 2005:183-191, 198-199).

22. See Low and Smith (2006). 
times able to make choices between massive modification (even including demolition) accompanied by a rhetoric of modernization on the one hand and careful preservation accompanied by a rhetoric of heritage and high culture on the other, according to what they saw as being in their best economic interests.

An ever-present danger is that in fighting the state in these terms, residents end up having to collude ideologically with it. The leadership of Pom Mahakan is at least partly aware of this danger, which represents what Verena Stolcke (1995; see also Holmes 2000) has identified as "cultural fundamentalism," although their loyalty to the fundamental institutions of the Thai state, and especially to the monarchy, is not negotiable and should not be doubted. They have identified the age of most of the older buildings on the site in terms of "reigns" (the dynastic succession), thus tying their fortunes to those of official historiography. In a country with strict laws protecting the monarchy from criticism and with a culture of consensus in public display and debate, the most effective strategy is always to represent one's cause as a refraction of the larger national (and royal) interest and to suggest that criticism of that cause therefore represents an offense against the latter. The deployment of unity, expressed through the use of national flags and royal portraits, is the only acceptable mode of protest, both because of the residents' own expressed sentiments and because, whether or not it works, that modality is at least seen as ethically and legally unassailable. $^{23}$

Hostile officials, on the other hand, dispute the community's status on the grounds that it is an agglomeration of people of very different backgrounds and places of origin. They also invoke the absence of documentary evidence of ownership and point to the considerable number of longterm squatters - squatters, be it noted, who were warmly welcomed by those already living on the site and who have contributed signally to the development of the sense of community that the municipal authorities' pressure tactics have only intensified still further.

It is the municipal bureaucrats' hostility that compels the Pom Mahakan leadership to play in the unifying conceptual field of dynastic succession and Thai nationalism rather than in that of distinct but overlapping histories and identities. ${ }^{24}$

23. When the Pom Mahakan residents requested the active support of the United Nations Committee on Cultural, Economic, and Social Rights in Geneva, the committee's letter was copied to the king. This allegedly infuriated municipal officials, but there was nothing they could do about it, and it afforded the residents some impunity in their ongoing struggle against eviction.

24. Byrne (2009), also writing about Thailand, develops a related position, suggesting that scholars should incorporate local understandings of cosmology in their engagements with historic conservation. While I warmly endorse the overall thrust of his argument, I find it ironic - and indicative of the larger context that we all must confront-that to advance it, and perhaps also impelled by the interesting but risky comparison he attempts between modern Thailand and medieval Europe, he deploys the category of "popular religion," a term that can inadvertently suggest a
Yet at least one of the leaders appears to be fully aware of the dangers of such an assimilationist approach, and in fact the small community museum-also protectively labeled "pavilion of the community's local knowledge" (saalaa phumipanyaa chumchon) in invocation of a current form of political correctness-contains plentiful materials that record the residents' struggles. Similarly, when I told the leaders that some officials appeared to dismiss their claims to community status on the grounds of multiple origins and that this seemed inconsistent with the assimilationist national self-image and ideology, the word diversity (khwaamlakhlaai) was suddenly part of the local vocabulary. Official rhetoric can be countered with language that expresses the internal tension between hierarchy and egalitarianism, or between cultural unity and creative difference, that is the hallmark of collective selfconception in the modern Thai polity. ${ }^{25}$

There is a parallel here with the way in which residents of Roman complexes like the building in Via degli Ibernesi lay claim to being the last of the ancient Romans. Here, the residents, disaffected by the apparent indifference of national politicians, are tempted into collusion by the political heirs of Mussolini and the pre-World War II fascists-politicians who are not averse to exploiting the disjunctures between national and local levels of identity and political action. ${ }^{26}$ Yet here, too, even those who were loudly criticized by leftist neighbors for their alleged collusion with a nasty form of rightist politics were acutely uncomfortable about the identification. What is an anthropologist to do in such cases? It is no use pretending to be neutral; even seeking balance is a political act. I involved two left-leaning and ecologically minded senators in the struggle; one of them also participated, along with other representatives of the governing coalition, in a press conference at which they were an important counterweight to the presence of neofascist leaders and operatives.

Clearly we cannot decide questions of social justice on the basis of political party affiliations. On the other hand, we can insist that a wide range of conceptual alternatives be deployed so that social actors can make well-informed choices. Globalization is a fact of life. But is does not have to be a neoliberal fact of life; indeed, it has been around for far longer than any currently dominant economic ideology. Moreover, the availability of choices means that we, too, have opportunities to

hegemonic categorization of official ("Buddhism") and local ("animism") as conceptually separate and mutually exclusive domains that happen to "overlap and entangle" (for an excellent critique of this dualism in the context of Greek religious practices today, see Stewart 1989). To be sure, he then forthrightly and quite rightly concludes that the alleged incompatibility of ritual with science is "one of the conceits of Western modernity," a point that makes his overall position much clearer. The Pom Mahakan residents and Thai positivists who invoke "Buddhism" to justify their conceptions of "data" show that active conceptual bricolage both dissolves such binaries and redeploys them for political ends.

25. I discuss this tension as it plays out in Pom Mahakan in a recent paper (M. Herzfeld, "Paradoxes of Order in Thai Community Politics," unpublished manuscript).

26. For an example of this, see Herzfeld (2009:283). 
demonstrate that a social ethic based on principles of mutual tolerance and respect and on the complexities of anthropological knowledge can have a genuine appeal and perhaps thereby also a lasting impact on the configuration of people's lives. The task before us is both clear and urgent. It is to make such complexities accessible and interesting to multiple publics at a time when they are being cynically targeted for the seductive and perhaps irreversible addiction of false simplicities.

\section{References Cited}

Abu El-Haj, Nadia. 2001. Facts on the ground: archaeological practice and territorial self-fashioning in Israeli society. Chicago: University of Chicago Press.

Borofsky, Robert. 1997. Cook, Lono, Obeyesekere, and Sahlins. Current Anthropology 38:255-282.

Bourdieu, Pierre. 1977. Outline of a theory of practice. R. Nice, trans. Cambridge: Cambridge University Press.

Byrne, Denis. 2009. Archaeology and the fortress of rationality. In Cosmopolitan archaeologies. Lynn Meskell, ed. Pp. 68-88. Durham, NC: Duke University Press.

D’Andrade, Roy. 1995. Moral models in anthropology (and reply). Current Anthropology 36:399-408, 433-438.

Desjarlais, Robert R. 1997. Shelter blues: sanity and selfhood among the homeless. Philadelphia: University of Pennsylvania Press.

Escobar, Arturo. 1995. Encountering development: the making and unmaking of the Third World. Princeton, NJ: Princeton University Press.

Ferguson, James. 1990. The anti-politics machine: development, depoliticization, and bureaucratic power in Lesotho. Cambridge: Cambridge University Press.

Fisher, William, ed. 1995. Toward sustainable development? struggling over India's Narmada River. Armonk, NY: Sharpe.

Giddens, Anthony. 1984. The constitution of society: introduction to the theory of structuration. Berkeley: University of California Press.

Gupta, Akhil. 1998. Postcolonial developments: agriculture in the making of modern India. Durham, NC: Duke University Press.

Hamilakis, Yannis. 2007. The nation and its ruins: antiquity, archaeology, and national imagination in Greece. Oxford: Oxford University Press.

Herzfeld, Michael. 1991. A place in history: monumental and social time in a Cretan town. Princeton, NJ: Princeton University Press.

. 1997. Anthropology and the politics of significance. Social Analysis 41:107-138.

- 1998. Factual fissures: claims and contexts. Annals of the American Academy of Political and Social Science 560:69-82.

2002. The absent presence: discourses of crypto-colonialism. South Atlantic Quarterly 101:899-926.

. 2003. Pom Mahakan: humanity and order in the historic center of Bangkok. Thailand Human Rights Journal 1:101-119.

- 2005. Cultural intimacy: social poetics in the nation-state. 2nd edition. New York: Routledge.

. 2006. Spatial cleansing: monumental vacuity and the idea of the West. Lournal of Material Culture 11:127-149.

- 2009. Evicted from eternity: the restructuring of modern Rome. Chicago: University of Chicago Press.

Holmes, Douglas R. 2000. Integral Europe: fast-capitalism, multiculturalism, neofascism. Princeton, NJ: Princeton University Press.
Hong, Lysa. 2004. "Stranger within the gates": knowing semi-colonial Siam as extraterritorials. Modern Asian Studies 38:327-354.

Jackson, Peter. 2004. The performative state: semicoloniality and the tyranny of images in modern Thailand. Sojourn: Social Issues in Southeast Asia 19:40-74.

- 2007. Autonomy and subordination in Thai history: the case for semicolonial analysis. Inter-Asia Cultural Studies 8:329-348.

Lloyd, G. E. R. 1990. Demystifying mentalities. Cambridge: Cambridge University Press.

Low, Setha, and Neil Smith, eds. 2006. The politics of public space. New York: Routledge.

Maier, Joseph H. 2002. The slaughterhouse. Bangkok: Post.

Marcus, Anthony. 2006. Where have all the homeless gone? the making and unmaking of a crisis. New York: Berghahn.

Massingham, Bruce. 2003. The assembly of the poor in Thailand: from local struggles to national protest movement. Chiang Mai, Thailand: Silkworm.

Meskell, Lynn. 2009. Introduction: cosmopolitan heritage ethics. In Cosmopolitan archaeologies. Lynn Meskell, ed. Pp. 1-27. Durham, NC: Duke University Press.

Obeyesekere, Gananath. 1992. The apotheosis of Captain Cook: European mythmaking in the Pacific. Princeton, NJ: Princeton University Press.

Pollis, Adamantia. 1987. The state, the law, and human rights in modern Greece. Human Rights Quarterly 9:587-614.

Sahlins, Marshall. 1985. Islands of history. Chicago: University of Chicago Press.

- 1995. How "natives" think: about Captain Cook, for example. Chicago: University of Chicago Press.

Shryock, Andrew. 1997. Nationalism and the genealogical imagination: oral history and textual authority in tribal Jordan. Berkeley: University of California Press.

Smith, Neil. 2006. Gentrification generalized: from local anomaly to urban "regeneration" as global urban strategy. In Frontiers of capital: ethnographic reflections on the new economy. Melissa S. Fisher and Greg Downey, eds. Pp. 191-208. Durham, NC: Duke University Press.

Stewart, Charles. 1989. Hegemony or rationality? the position of the supernatural in modern Greece. Lournal of Modern Greek Studies 7:77-104.

Stolcke, Verena. 1995. Talking culture: new boundaries, new rhetorics of exclusion in Europe. Current Anthropology 36:1-24.

Thanaphon, Watthanakun. 2007. Kaanmoeang roeang phoen thii: pholawat thang sangkhom khong chumchon (koronii soeksaa: chumchon Pom Mahaakaan) [Politics of place: social dynamics of a community (case study: the Pom Mahakan community)]. Bangkok: 14 October Scholarly Institutional Foundation.

Thompson, Michael. 1979. Rubbish theory: the creation and destruction of value. New York: Oxford University Press.

Thongchai, Winichakul. 2001. Prawatisat thai baep rachaachaatniyom: jaak yuk anaanikhom amphraang suu rachaachaatniyom mai roea laatthi Sadet Phaw khong kradumphii thai nai pachuban [Royalist Thai history: from the crypto-colonial era to the new royalism of the cult of Rama $\mathrm{V}$ among the present-day Thai middle class]. Silapawathanatham 23(1):56-64.

2002. The quest for Siwilai: a geographical discourse of civilizational thinking in the late nineteenth and early twentiethcentury Siam. Journal of Asian Studies 59:528-549.

Wilson, Richard Ashby, and Jon P. Mitchell. 2003. Introduction. In Human rights in global perspective: anthropological studies of rights, claims and entitlements. Richard Ashby Wilson and Jon P. Mitchell, eds. Pp. 1-15. London: Routledge. 